\title{
ФОРМУВАННЯ ТА РОЗВИТОК ГОЛОВНИХ ПРИНЦИПІВ ТЕАТРАЛЬНОÏ СИСТЕМИ М. ЧЕХОВА В КОНТЕКСТІ ЗМІНИ СВІТОСПРИЙНЯТТЯ АКТОРА
}

\author{
Наталія Донченко ${ }^{1 a}$, Наталія Соколенкоª \\ 1 заслужений діяч мистецтв України, професор; \\ e-mail: donchenko.nata1@gmail.com; ORCID: 0000-0003-1484-6800 \\ ${ }^{2}$ магістр; e-mail: quitrack23@gmail.com; ORCID: 0000-0002-5978-2807

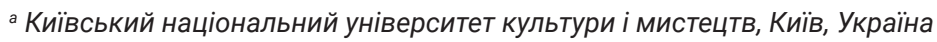

\section{Анотація}

Мета роботи - проаналізувати формування та розвиток головних принципів театральної системиМ. Чеховавконтекстізмінисвітосприйняттяакторатеатральногомистецтва. Дослідити театрально-педагогічну систему М. Чехова як одну зпровіднихсвітових театральнихпрактик, як синтез складних взаємодоповнювальних та взаємозбагачувальних міжкультурних процесів; визначити вплив митця на реформування європейської й американської школи акторського мистецтва. Методологія дослідження базується на використанні таких наукових підходів: когнітивного - для поглибленого вивчення багатогранності творчої діяльності М. Чехова як автора унікальної акторської «Системи Чехова»; культурологічного - для зіставлення та порівняння історичних, педагогічних і мистецтвознавчих складових у діяльності М. Чехова; аналітичного - для виявлення основних принципів методики акторської майстерності М. Чехова. Наукова новизна. Досліджено акторську та режисерську діяльність М. Чехова в контексті особливостей методики підготовки акторів і розробки власного методу гармонізації постановки; визначено специфіку новаторських концепцій методів театральної режисури М. Чехова; схарактеризовано вплив режисерської діяльності майстра на розвиток сучасної світової театральної практики в контексті світосприйняття актора. Висновки. Діяльність М. Чехова була спрямована на створення нового театру як у прямому, так і в переносному сенсі за допомогою техніки, розробленої шляхом навчання та експериментів. Дослідження методики Михайла Чехова в контексті специфіки сучасного акторського навчання дає змогу зауважити, що ставлення до творчого та педагогічного спадку М. Чехова особливе, оскільки визнані професійні актори понад пів століття вважають його методику фундаментом для подальших творчих пошуків, а розроблені для акторського тренінгу вправи - основою власної техніки.

Ключові слова: актор; режисер; Михайло Чехов; метод; техніка актора; «психологічний жест»; «ритмічний жест ідеї» 


\section{Постановка проблеми}

Творча спадщина М. Чехова - відомого актора, режисера і театрального педагога, ідеї якого за життя нерідко розглядали як занадто радикальні та містичні, протягом останніх десятиліть і на сучасному етапі привертають неабияку увагу зарубіжних та вітчизняних дослідників, що є важливим поштовхом не тільки для осмислення й інтегрування творчих напрацювань видатного майстра сцени в сучасний театральний простір, а й для подальшого розвитку сценічного мистецтва.

Позиціонування цілісної театрально-педагогічної системи М. Чехова як однієї з провідних у світовій театральній практиці, яка виникла унаслідок складної взаємодії різноманітних, взаємодоповнювальних та взаємозбагачувальних міжкультурних процесів, вимагає проведення ґрунтовного дослідження її особливостей у контексті зміни світосприйняття режисера, специфіки елементів запропонованої виконавської техніки та вправ, розроблених протягом багаторічної професійної творчої діяльності в Росії та в еміграції. Проте, незважаючи на велику кількість теоретичних праць, присвячених осмисленню його методу, втім, як і практичному опануванню, феномен системи М. Чехова з багатьох причин і досі лишається недостатньо вивченим.

Система М. Чехова є однією з традиційних методик американської школи акторської підготовки, яка еволюціонує завдяки створенню нових підходів і тренінгів, адаптованих до відображення сучасних поглядів суспільства.

\section{Аналіз останніх досліджень і публікацій}

Важливими джерелами інформації, які посприяли здійсненню детального дослідження, стали теоретичні та практичні праці Рудольфа Штайнера (McDermott ed., 1984) та «Лекція з евритмії» від 26 серпня 1923 року (Steiner, 1927) про духовні основоположні принципи рухів виконавців; Михайла Чехова, зокрема «Шлях актора», «Про техніку актора»; також листи і статті майстра, такі як «Колективу МХАТ 2-го» від 29 серпня 1928 р., «К. С. Станіславському», квітень 1930 р. та ін.

А також проаналізовано наукові публікації сучасних дослідників: О. Кузіної «Психологічний жест - ключ до гри актора в методі Михайла Чехова», в якій розглянуто психологічний жест як ключовий інтегральний елемент, пов'язаний з репетиційними прийомами акторської техніки М. Чехова, а також описано вправи, що сприяють актору заволодіти ігровим існуванням на сцені, та «Ігрова природа вправ Михайла Чехова»; Ю. Тітова "“Звукопис" Михайла Чехова як таємне володіння словом», в якій автор, аналізуючи спогади відомих акторів про гру М. Чехова, підходить до вивчення звукової побудови ролі майстром і визначає головні принципи у створенні його безсмертних образів, та «Антропологічний принцип в мистецтві Михайла Чехова»; В. Золотухіна «Недовіра слову. Нотатки про фрагменти ролей Михайла Чехова із зібрань КІХРа», М. Іванова «Літопис життя і творчості М. А. Чехова», В. Поліщук «Акторський тренінг Михайла Чехова», С. Юрського «Спроба мислити» та ін. 
Вісник Київського національного університету культури і мистецтв.

Серія: Сценічне мистецтво

Мета роботи - проаналізувати формування та розвиток головних принципів театральної системи М. Чехова в контексті зміни світосприйняття актора театрального мистецтва.

\section{Виклад основного матеріалу}

Михайло Чехов (1891, Санкт-Петербург, Російська імперія - 1955, БеверліГіллз, Каліфорнія, США) - один з видатних представників театральної педагогіки, головним призначенням театру вважав виховання релігійності, тобто духовності (Чехов, 2007, с.324). Унаслідок багаторічного дослідження акторської та режисерської професій, структури театрального простору та методів впливу театру на глядача він створив унікальну систему, яка, на думку багатьох дослідників, спрямована піднести театр разом з актором і глядачем на недосяжний духовний рівень (Коробейников, 2014, с.244). Відповідно до поглядів М. Чехова артист має пізнати духовну істину, а інакше він не спроможний впливати на глядача та перестає бути актором, перетворюючись лише на зображення. Отже, духовна сліпота несумісна з творчим початком художника загалом, зокрема й актора.

Варто зазначити, що методи М. Чехова вдало застосовують не лише в професійній театральній практиці. Спрямована насамперед на вивільнення особистісних якостей і відкриття індивідуальних рис характеру методика широко використовується в педагогіці та психології (Полищук, 2010, с. 19).

Протягом понад пів століття театрально-педагогічна система М. Чехова є однією з найвідоміших традиційних систем акторської підготовки в Сполучених Штатах Америки, якісно вплинувши на розвиток американської школи акторського мистецтва.

Безумовно, час роботи актором МХАТу, який очолював К. С. Станіславський, посприяв формуванню базових знань М. Чехова, що стали в пригоді у подальших теоретичних і практичних пошуках, у тому числі написанні театральних праць і розробці авторської системи підготовки актора. Характеризуючи акторську гру М. Чехова цього періоду, дослідники зазначають, що в ній поєднано «вибухову суміш екстрактів натуралізму та символізму з єдиною художньо-філософською метафорою живої конкретності буття та космічних злетів Духу» (Кирилов, 2008, с.19), а засобами виконавської психофізики відображалися найгостріші риси характерності та піки абстракції буття.

Невдоволення від роботи з К. Станіславським над роллю Треплєва в «Чайці», розчарування в сучасному театрі, творча та духовна криза (Иванова, 2013, с. 15) спричинили стан глибокої депресії, вийти з якої М. Чехов зумів самотужки завдяки зацікавленням філософськими й естетичними вченнями (передусім філософією всеєдинства Вл. Соловйова), релігіями, теософією та різноманітними містичними течіями.

у 1919 р. у журналі «Горн» М. Чехов опублікував статті «Про систему Станіславського» та «Про роботу актора над собою» (Чехов, 1995а, с.31), в яких здійснив спробу обґрунтувати необхідність системи у процесі підготовки актора. Проте 
серед театральних режисерів і педагогів публікації викликали досить жорстку критику. Так, наприклад, у статті Є. Вахтангова «Тим, хто пише про «систему» Станіславського» вказано на великі недоліки, які М. Чехов допустив, по-перше, написавши про методику системи, раніше за самого її автора - К. Станіславського; по-друге, спробувавши викласти складну методичну систему в невеликій за обсягом статті (3-4 сторінки); по-третє, зробивши це досить непослідовно та безсистемно (Вахтангов, 1984, с.300-303).

Утім, подібна критика лише підштовхнула М. Чехова до осмислення та обґрунтування власної системи акторської підготовки, відправною точкою створення якої стали погляди актора, які не відповідали принципам К. Станіславського. Так, наприклад, на відміну від Станіславського, який вважав, що актор має йти до ролі «від себе», тобто з огляду на «правду переживань», М. Чехов зазначав, що акторське «Я» - носій егоцентричної акторської свідомості - не може виступати як матеріал ролі, оскільки це в кращому разі призводить до «нудьги» на сцені. Осмислення того, що художній образ - це щось очищене від повсякденних почуттів актора, посприяло розумінню М. Чеховим того, що світ художніх образів існує поза людиною.

Варто зазначити, що неабиякий вплив на формування методу М. Чехова здійснив романіст, поет, драматург і теоретик А. Бєлий, творчий процес якого був надзвичайно цікавий - він придумував загальний план роману, а потім терпляче спостерігав за персонажами, яких він оживив, які оточували його день за днем, як вони розвивалися, намагаючись встановити відносини між собою, змінюючи сюжет і розкриваючи більш глибокий сенс (Chekhov and Merlin eds., 2005, p.58). Відтак художня уява А. Бєлого здатна була поєднувати два процеси, які є взаємовиключенням. Це дало змогу зображенням, які він створював, існувати автономно, водночас підкорюючись волі художника. У той час як він спостерігав за об'єктивною взаємодією цих образів, його проникливість наділяла їх власними суб'єктивними елементами.

Отже, А. Бєлий не тільки взаємодіяв зі своїми творчими образами, а й включав їх у процес, який стане центральним у підході М. Чехова і матиме вирішальне значення для його техніки психологічного жесту.

Варто зазначити, що на творчість А. Бєлого також надзвичайно сильно вплинула антропософія Р. Штайнера, австрійського доктора філософії, окультиста та соціального реформатора, відтак стає цілком зрозумілим той факт, що невдовзі їм починає захоплюватися і М. Чехов.

Незважаючи на досить неоднозначні оцінки впливу антропософії на творчість М. Чехова сучасних театрознавців (є думки, що Р. Штайнер «згубив стихійний геній актора власним витонченим раціоналізмом») (Иванов, 2000, с.85), у передмові до першого видання праці «Про техніку актора» (1946р.) знаходимо такі рядки: «Моя багатолітня робота в галузі Антропософії Рудольфа Штайнера дала мені керівну ідею для всієї роботи в цілому» (Бюклинг, 2000, с.462).

Саме на основі комбінування осмисленої, відповідно до власного світобачення, антропософії Р. Штайнера та методу К. Станіславського М. Чехов почав розробляти власний «психофізичний» підхід до сценічного виконавства. 
Вісник Київського національного університету культури і мистецтв. Серія: Сценічне мистецтво

Дослідники життя і творчості М. Чехова зазначають, що протягом 19201922 рр., з моменту першого знайомства актора з вченням Р. Штайнера та до часу призначення його керівником Першої студії МХАТ, він з людини «похмурої, часом неприборканої та нестриманої... який висловлював суперечливі думки і не бажав стримувати власних потягів» (Чехов, 1995b, с.100), перетворився на ідейного та художнього лідера, реформатора театрального мистецтва, який мріяв про створення самостійної системи акторської творчості (Кирилов, 2008, с.483), викладав у студіях Пролеткульту та Студії імені Ф. Шаляпіна, а також грав головні ролі в постановках К. Станіславського «Ревізор» та Є. Вахтангова «Ерік XIV».

Діяльність, яку розпочав М. Чехов наприкінці 1922 р., розвивалася протягом 20-ти років і була пов'язана з втіленням ідеї створення нового, одухотвореного театру та виховання актора нового типу - своєрідне продовження традицій, започаткованих К. Станіславським. На думку В. Золотухіна, маніфестом нового, естетичного, незалежного театру стала вистава Стріндберга «Ерік XIV», в якій М. Чехов зіграв головну роль. Режисер $€$. Вахтангов у творчих суперечках із системою К. Станіславського розкрив експресіоністську спрямованість театру й означив початок періоду пошуку театральних форм (Золотухин, 2014).

Зазначимо, що проблематика спільних і відмінних рис двох відомих традиційних систем акторської підготовки - К. Станіславського та М. Чехова - неодноразово ставала темою ґрунтовних наукових досліджень вітчизняних і зарубіжних науковців.

Так, наприклад, на думку деяких дослідників, головна відмінність системи М. Чехова від системи К. Станіславського полягає в різноманітному осмисленні процесу роботи над образом - замість позиціонування образу як результату акторської діяльності, М. Чехов зробив його щоденним матеріалом для роботи, сформувавши нову концепцію створення сценічного образу актора - концепцію імітації, відповідно до якої актор має створювати образ у власній уяві, а потім імітувати внутрішні та зовнішні якості. Цікавими та доцільними, на нашу думку, є висновки С. Юрського (2003, с.130-135), який зазначав, що методика М. Чехова унеможливлює спробу актора приховати відсутність здібностей, оскільки в процесі створення художнього образу використовується протилежний шлях, аніж «від простої органічності до образу занадто далекого», відтак $є$ досить небезпечною не тільки для актора-початківця, а й для досвідченого професіонала. На думку М. Гордона, якщо К. Станіславський мріяв про досконалу систему акторського навчання, то М. Чехов ще й про «досконалий стиль акторського мистецтва - доповнений широким та глибоким компонентом, який більше резонує з радісною релігійністю грецьких класиків, аніж вбогою комерціалізацією та політикою Росії того періоду» (Gordon, 1985, p. 14).

На думку А. Кирилова, відкриття М. Чеховим власного методу не було передбачуваним самим актором явищем, а скоріше результатом нагальної необхідності подолати обмеження та протиріччя, з якими колишні учні К. Станіславського зіткнулися в процесі сценічної діяльності. Прагнучи розв'язати ці проблеми, М. Чехов звернувся до творчих можливостей акторської уяви та відмовився від використання в грі особистих переживань, вважаючи, що емоційний досвід кожного окремого індивідуума перебуває в іншому вимірі, ніж «ідеальна» галузь 
мистецтва. Відтак переорієнтація на уявний образ, який є ідеальним за власною природою, посприяла об'єктивній творчості та звільнила актора від диктатури власної особистості. Перехід до методу фантазування (тобто уяви) та імітації образу дослідник позиціонує як відмежування М. Чехова від Театру К. Станіславського і початок власного пошуку ідеальної природи акторського мистецтва зокрема, і театрального загалом (Кирилов, 2008, с.20).

М. Чехов присвятив свою творчу діяльність переосмисленню театрального мистецтва з позиції становлення нового світосприйняття, працюючи в Німеччині, Австрії, Франції, Латвії, Литві та, зрештою, в Англії, створивши першу англомовну школу акторського навчання в Європі. Враховуючи, що театр у Росії та Східній Європі був і залишається в центрі національної культури, М. Чехов відчув обов'язки, пов'язані з його підходом до режисури, який поєднував етичні й соціальні проблеми. Як у постановках того періоду, так і під час занять у студії він намагався розвивати зміни в театральному мистецтві на шляху до нового театру.

Розроблений Р. Штайнером та його послідовниками художній принцип і педагогічна методика евритмія - мистецтво художнього руху, засноване на глибинному переживанні та розумінні краси і законів музики й мови, здійснило великий вплив на формування чеховської техніки психологічного жесту.

М. Чехов детальніше починає вивчати праці Р. Штайнера, зрозумівши, що «жести, створені мною, були створені випадково» (Chekhov and Merlin eds., 2005, p.188), у тому числі практикуючи медитативні вправи, описані в книзі Р. Штайнера «Як досягнути пізнання вищих світів?», в якій подано керівництво до духовного навчання, через процес, який починається з того, що Р. Штайнер називає «підготовкою» - «спрямування уваги душі до певної події довкола нас: з одного боку, життя, яке росте, розквітає, квітне, а з іншого - всі явища згасання, розпаду» (Steiner, 1967, р.46). М. Чехов, описуючи свої практики, зазначає, що, лежачи в садку в яскравий сонячний день, спостерігав за гармонійними формами рослин, уявляючи процес обертання Землі та планет, шукаючи гармонійні композиції в космосі та поступово переходячи до досвіду руху, небаченого зовнішнім оком, руху, який присутній в усіх явищах природи. Він наголошує:

«Це був рух, який створив форму і досі підтримував їі. Я назвав цей невидимий рух, цю гру сил «жестом» і мені здалося, ніби я через нього можу проникнути в саму суть явища. Коли я тоді виконав жести, які створив сам, вони незмінно викликали почуття та імпульси волі в мені і породжували творчі образи». (Chekhov and Merlin eds., 2005, p.187-188)

Цей досвід М. Чехов перетворив на вправу з техніки «психологічний жест».

У М. Чехова поступово розвинулося прагнення знайти засоби, які б надали гармонії театральній постановці. Необхідність гармонізації посприяла пошуку нових методів, тому він повинен був стати режисером. М. Чехов розробив власний метод гармонізації постановки, але в ролі режисера помітив, що його можливості обмежені, оскільки акторам, які навчені старими способами, було нелегко сприйняти нові ідеї та освоїти нову техніку. Відтак його розум природним чином перейшов до наступного кроку - нові актори нового театру мають бути навчені за його методикою, а відтак він мав стати педагогом. Отже, шлях від актора до 
Вісник Київського національного університету культури і мистецтв. Серія: Сценічне мистецтво

режисера, а від режисера до педагога становить логічну послідовність, а кожна зміна зумовлена необхідністю розв'язання проблем (The Chekhov Theatre Studio, 1936, pp.32-33).

Свого часу К. Станіславський надав М. Чехову приклад студійної практики, яка лишалася його ідеалом, а також модель для розвитку художньої техніки. К. Станіславський радив М. Чехову «організувати та записати свої думки про техніку акторської дії» (Chekhov, 2002, рр.160-161). Зазначимо, що М. Чехов спостерігав закономірність розвитку системи К. Станіславського, поєднуючи стабільність техніки з інтуїтивною нестабільністю практики.

Для обох театральних педагогів творчість була інтуїтивним процесом, що згодом має бути сформульований за допомогою інтелекту в техніку, яку можна практикувати та розвивати.

Відома техніка М. Чехова «психологічний жест» була визначена М. Пауерсом як «рух, який втілює психологію і мету персонажа» (Chekhov and Gordon eds., 1991, p.38), створений з метою сформувати та налаштувати своє внутрішнє життя відповідно до його художньої мети і завдання (Chekhov, 2002, p.66).

Відмінність методів М. Чехова і К. Станіславського визначилася під час їх останньої зустрічі, на якій, як згадує М. Чехов, обговорено «дві проблеми, які нас розділяють: використання афективної пам'яті та способи створення персонажа». Так, К. Станіславський стверджував, що актор має спиратися на «своє власне, інтимне життя» в обох випадках, викликаючи емоції та відкриваючи персонажа, уявляючи себе в ситуації, в якій той знаходиться. Для М. Чехова ж актор має забути себе і використовувати творчі почуття й образ персонажа, «очищений від особистісного елемента» (Chekhov and Merlin eds., 2005, p.39). Тобто головна дискусія точилася довкола питання, чи потрібно позбавлятися особистих, нетрансформованих почуттів актора під час творчого процесу. Для М. Чехова «особисті нетрансформовані почуття» не мали відношення до творчого процесу, який він розглядав як взаємодію між художником і образами, що мають автономне життя.

У процесі навчання студійців М. Чехов постійно згадував цей ідеал ансамблевого співробітництва та необхідність запровадження нового типу розмови в театрі, яка має розвиватися між акторами, драматургами, режисерами, сценографами тощо - мова постановки, яка дасть змогу театральним артистам розробляти матеріал для вистави і передавати духовний зміст цього матеріалу глядачу.

Дослідження п'єс у студії М. Чехова розпочиналося із сутності твору, під якою він розумів «керівну ідею» (Chekhov and Hurst du Prey eds., 2000, pp.43-44). Вважаючи, що рух - це мова театру, така ж як і слова, а тому репетиції з рухами посприяють створенню нової мови, яка стане згодом мовою театральною, він позиціонував сутність п'єси як центральну для мови руху театру, а її форма була визначена жестом (Chekhov, 2002, р.68).

Зазначимо, що термін «ритмічний жест ідеї» М. Чехов винайшов під час роботи в студії. Це поняття він лише почав досліджувати та розробляти разом зі студійцями, акцентуючи, що воно найголовніше й «може бути сутністю, ідеєю, ритмом і всім іншим, тому було б невірним розуміти ці терміни як щось окреме - це одне» (M., 1983). 
М. Чехов розробив цей «ритмічний жест ідеї» для п'єси, розпочавши з дослідження атмосфер, а потім образів персонажів. Він також використовував цей жест для дослідження мови в атмосфері п'єси, пропонуючи студійцям віднайти, який саме жест є в їхніх словах, наголошуючи, що спочатку потрібно знайти жест, а лише потім - правильну мову, бо «у кожного слова є жест, і ми повинні знайти його в гармонії з атмосферою» (М., 1983). Найголовнішим є створення атмосферою, образами та жестами композиційної динаміки п'єси, яка містить усі елементи постановки. Психологія ж сценічного простору має стати гармонійним цілим з актором. Гармонійним, проте індивідуальним для кожної п'єси, конкретний світ якої має бути досліджений.

Окремим аспектом у методиці М. Чехова є вивчення п'єси, а саме її історії, історичних цінностей, костюмів тощо - своєрідне дослідження з метою осмислення світу, в якому відбувається дія п'єси, оскільки кожна акторська гра має відбуватися в контексті особливого світу. Зважаючи на те, що ці аспекти п'єси мали власну психологію, він використовував психологічний жест, щоб ввести їх у живу тканину вистави. За його словами, саме жест дає змогу дійсно виразити те, що він збирається зробити як актор, зокрема ідею, інтерпретацію, дію, текст, оскільки саме жести лежать в основі тексту, почуттів, атмосфери та ін. (М., 1983).

Отож, техніка М. Чехова виходить за межі (проте не руйнує їх повністю) бінарної різниці між духом і матерією, пропонуючи розглядати виконавця як митця, майстерність якого полягає у створенні нематеріального матеріалу вистави.

М. Чехов довів до крайнощів орієнтації системи К. Станіславського в її перший період, коли етика та духовність були опорами підходу до акторської дії, без критичного судження і заснованого на емпатії.

Проте саме ця духовність привела його учнів до перебування актора в новому стані. Як свідчить Ф. Мейсон у мемуарах, «нас часто повністю переносили за межі нашого звичного "Я". Ми були розширені до нового виміру, в якому не було ніяковіння» (Бюклинг, 2000, с.5).

Новизна дослідження. Уперше систематизовано й аналітично осмислено акторську та режисерську діяльність М. Чехова в контексті особливостей методики підготовки акторів і розробки власного методу гармонізації постановки; визначено специфіку новаторських концепцій методів театральної режисури М. Чехова; схарактеризовано вплив режисерської діяльності майстра на розвиток сучасної світової театральної практики в контексті світосприйняття актора.

\section{Висновки}

Діяльність М. Чехова була спрямована на створення нового театру як у прямому, так і в переносному сенсі за допомогою техніки, розробленої шляхом навчання та експериментів.

Дослідження методики Михайла Чехова в контексті специфіки сучасного акторського навчання дає змогу зауважити, що ставлення до творчого та педагогічного спадку М. Чехова особливе, оскільки визнані професійні актори понад пів 
століття вважають його методику фундаментом для подальших творчих пошуків, а розроблені для акторського тренінгу вправи - основою власної техніки.

Створені наприкінці XX - на початку XXI ст. театральні студії М. Чехова популяризують сформований ним метод навчання актора, який на сучасному етапі відроджується та інтегрується багатьма світовими театральними практиками у творчий і навчальний процес, здебільшого в їх власних інтерпретаціях, які позиціонуються як продовження еволюціонування театрально-педагогічної системи Михайла Чехова.

\section{СПИСОК ПОСИЛАНЬ}

Бюклинг, Л., 2000. Михаил Чехов в Западном театре и кино. Санкт-Петербург: Академический проект.

Вахтангов, Е., 1984. Пишущим о «системе» Станиславского В: Вендровская, Л.Д. и Каптерева, Г.П. сост., 1984. Вахтангов Евгений. Москва: ВТО.

Золотухин, В., 2014. Недоверие слову. Заметки о фрагментах ролей Михаила Чехова из собрания КИХРа. Театр, [online] 16. Доступно: <http://oteatre.info/nedoverie-slovu-zametkio-fragmentah-rolej-mihaila-chehova-iz-sobraniya-kihra/\#footnote_10_10619> [Дата обращения 05 сентября 2020].

Иванов, В., 2000. Лекции Рудольфа Штайнера о драматическом искусстве в изложении Михаила Чехова. Письма актера к В. А. Громову. В: Мнемозина. Документы и факты из истории отечественного театра XX в. Москва: Эдиториал УРСС. Т. 2.

Иванова, А.А., 2013. Михаил Чехов: антропософия и поиск духовного пути. Театрон, 1 (11), с.15-32.

Иванова, М.С., 1995. Летопись жизни и творчества М.А. Чехова. В: Чехов М. Литературное наследие. Москва: Искусство. Т. 2.

Кирилов, А.О., 2008. Театр и театральная система Михаила Чехова. Кандидат искусствоведения. Российский институт истории искусства.

Коробейников, Д.В., 2014. Духовная основа принципов театральной системы М.А. Чехова. Вестник Московского государственного университета культуры и искусств, 1 (57), c. 243-246.

Полищук, В., 2010. Актерский тренинг Михаила чехова, сделавший звездами Мерилин Монро, Джека Николсона, Харви Кейтеля, Бреда Питта, Аль Пачино, Роберта де Ниро и еще 165 обладателей премии «Оскар». Москва: АСТ.

Чехов, М., 1995а. Литературное наследие. 2-е изд. Москва: Искусство. Т. 2. Об искусстве актера.

Чехов, М., 1995b. Путь актера. В: Чехов, М. Литературное наследие. Москва: Искусство. Т. 1. Чехов, М.А., 2007. Путь актера: жизнь и встречи. Москва: АСТ.

Юрский, С.Ю., 2003. Попытка думать. Москва: Вагриус.

Chekhov, M. and Gordon, M. eds., 1991. On the Technique of Acting. New York: Harper Collins.

Chekhov, M. and Hurst du Prey D. eds., 2000. Michael Chekhov lessons for teachers of his acting technique. Ottawa: Dovehouse.

Chekhov, M. and Merlin, B. eds., 2005. The Path of the Actor. London: Routledge.

Chekhov, M., 2002. To the Actor. London: Routledge. 
Gordon, M., 1985. Introduction. In: Chekhov M. Lessons for the Professional Actor. New York: PAJ Books.

M., G., 1983. Chekhov on Acting: A Collection of Unpublished Materials (1919-1942). The Drama Review: TDR, 27(3). doi:10.2307/1145460

McDermott, R.A. ed., 1984. The Essential Steiner: Basic Writings of Rudolf Steiner: Knowledge, Nature, and Spirit; Spiritual Anthropology; Historical Vision; Esoteric Christianity; Society and Education by Rudolf Steiner.

Steiner R., 1927. Eurythmie als sichtbare Sprache. Laut-Eurythmie-Kurs. Dorna: PhilosophischAnthroposophischer Verlag am Goetheanum.

Steiner, R.A, 1967. Lecture on Eurythmy Given at Penmaenmawr on 26th August, 1923. London: Rudolf Steiner Press.

The Chekhov Theatre Studio, 1936. London: The Curwen Press.

\section{REFERENCES}

Bjukling L., 2000. Mihail Chehov $v$ Zapadnom teatre $i$ kino [Mikhail Chekhov in the Western theater and cinema]. St. Petersburg: Akademicheskij proekt.

Chehov, M., 1995a. Literaturnoe nasledie [Literary heritage]. 2nd ed. Moscow: Iskusstvo. T. 2. Ob iskusstve aktera [About the art of the actor].

Chehov, M., 1995b. Put aktera [The way of the actor]. In: Chehov, M. Literaturnoe nasledie [Literary heritage]. Moscow: Iskusstvo. T. 1.

Chehov, M., 2007. Put aktera: zhizn i vstrechi [The way of the actor: life and meetings]. Moscow: AST.

Chekhov, M. and Gordon, M. eds., 1991. On the Technique of Acting. New York: Harper Collins.

Chekhov, M. and Hurst du Prey D. eds., 2000. Michael Chekhov lessons for teachers of his acting technique. Ottawa: Dovehouse.

Chekhov, M. and Merlin, B. eds., 2005. The Path of the Actor. London: Routledge.

Chekhov, M., 1983. From class notes taken by Deidre Hurst Du Prey at Dartington Hall. Drama Review, 27 (3).

Chekhov, M., 2002. To the Actor. London: Routledge.

Gordon, M., 1985. Introduction. In: Chekhov, M. Lessons for the Professional Actor. New York: PAJ Books.

Ivanov, V., 2000. Lekcii Rudolfa Shtajnera o dramaticheskom iskusstve v izlozhenii Mihaila Chehova. Pisma aktera k V. A. Gromovu [Lectures of Rudolf Steiner on dramatic art as presented by Mikhail Chekhov. Letters from the actor to V.A. Gromov]. In: Mnemozina. Dokumenty i fakty iz istorii otechestvennogo teatra $X X v$. [Mnemosyne. Documents and facts from the history of the Russian theater of the XX century]. Moscow: Jeditorial URSS. T. 2.

Ivanova, A.A., 2013. Mihail Chehov: antroposofija i poisk duhovnogo puti [Mikhail Chekhov: anthroposophy and the search for the spiritual path]. Teatron, 1 (11), pp.15-32.

Ivanova, M.S., 1995. Letopis zhizni i tvorchestva M.A. Chehova [Chronicle of the life and work of MA. Chekhov]. In: Chehov M. Literaturnoe nasledie [Literary heritage]. Moscow: Iskusstvo. T. 2. Jurskij, S.Ju., 2003. Popytka dumat [An attempt to think]. Moscow: Vagrius.

Kirilov, A.O., 2008. Teatr i teatralnaja sistema Mihaila Chehova [Theater and theater system of Mikhail Chekhov]. Ph.D. in History of Arts. Russian institute of art history. 
Korobejnikov, D.V., 2014. Duhovnaja osnova principov teatralnoj sistemy M.A. Chehova [The spiritual basis of the principles of the theatrical system of M.A. Chekhov]. Vestnik Moskovskogo gosudarstvennogo universiteta kultury $i$ iskusstv, 1 (57), pp.243-246.

M., G., 1983. Chekhov on Acting: A Collection of Unpublished Materials (1919-1942). The Drama Review: TDR, 27(3). doi:10.2307/1145460

Polishhuk, V., 2010. Akterskij trening Mihaila chehova, sdelavshij zvezdami Merilin Monro, Dzheka Nikolsona, Harvi Kejtelja, Breda Pitta, Al Pachino, Roberta de Niro i eshhe 165 obladatelej premii "Oskar" [Mikhail Chekhovs acting training that made Marilyn Monroe, Jack Nicholson, Harvey Keitel, Brad Pitt, Al Pacino, Robert De Niro and 165 more Oscar winners stars]. Moscow: AST.

Steiner R., 1927. Eurythmie als sichtbare Sprache. Laut-Eurythmie-Kurs. Dorna: PhilosophischAnthroposophischer Verlag am Goetheanum.

Steiner, R.A, 1967. Lecture on Eurythmy Given at Penmaenmawr on 26th August, 1923. London: Rudolf Steiner Press.

The Chekhov Theatre Studio, 1936. London: The Curwen Press.

Vakhtangov, E., 1984. Pishushchim o "sisteme" Stanislavskogo [Writing about Stanislavskys system]. In: Vendrovskaja, L.D. and Kaptereva, G.P. comp., 1984. Vahtangov Evgenij [Vakhtangov Evgeniy]. Moscow: VTO.

Zolotuhin, V., 2014. Nedoverie slovu. Zametki o fragmentah rolej Mihaila Chehova iz sobranija KIHRa [Distrust of the word. Notes on fragments of the roles of Mikhail Chekhov from the collection of the KIHR]. Teatr, [online] 16. Available at: <http://oteatre.info/nedoverie-slovuzametki-o-fragmentah-rolej-mihaila-chehova-iz-sobraniya-kihra/\#footnote_10_10619> [Accessed 05 September 2020].

\title{
ФОРМИРОВАНИЕ И РАЗВИТИЕ ГЛАВНЫХ ПРИНЦИПОВ ТЕАТРАЛЬНОЙ СИСТЕМЫ М. ЧЕХОВА В КОНТЕКСТЕ ИЗМЕНЕНИЯ МИРОВОСПРИЯТИЯ АКТЕРА
}

\author{
Наталия Донченко ${ }^{1 a}$, Наталия Соколенкоª \\ ${ }^{1}$ заслуженный деятель искусств Украины, профессор; \\ e-mail: donchenko.nata1@gmail.com; ORCID: 0000-0003-1484-6800 \\ ${ }_{2}^{2}$ магистр; e-mail: quitrack23@gmail.com; ORCID: 0000-0002-5978-2807 \\ а Киевский национальный университет культуры и искусств, Киев, Украина
}

\begin{abstract}
Аннотация
Цель работы - проанализировать формирование и развитие главных принципов театральной системы М. Чехова в контексте изменения мировосприятия актера театрального искусства. Исследовать театрально-педагогическую систему М. Чехова как одну из ведущих мировых театральных практик, как синтез сложных взаимодополняющих и взаимообогащающих межкультурных процессов; определить влияние художника на реформирование европейской и американской школы актерского искусства. Методология исследования базируется на использовании таких научных подходов: когнитивного - для углубленного изучения
\end{abstract}


многогранности творческой деятельности М. Чехова как автора уникальной актерской «Системы Чехова»; культурологического - для сопоставления и сравнения исторических, педагогических и искусствоведческих составляющих в деятельности М. Чехова; аналитического - для выявления основных принципов методики актерского мастерства М. Чехова. Научная новизна. Исследована актерская и режиссерская деятельность М. Чехова в контексте особенностей методики подготовки актеров и разработки собственного метода гармонизации постановки; определена специфика новаторских концепций методов театральной режиссуры М. Чехова; охарактеризовано влияние режиссерской деятельности мастера на развитие современной мировой театральной практики в контексте мировосприятия актера. Выводы. Деятельность М. Чехова была направлена на создание нового театра как в прямом, так и в переносном смысле с помощью техники, разработанной путем обучения и экспериментов. Исследование методики Михаила Чехова в контексте специфики современного актерского обучения позволяет заметить, что отношение к творческому и педагогическому наследию М. Чехова особенное, поскольку признаны профессиональные актеры более полувека считают его методику фундаментом для дальнейших творческих поисков, а разработанные для актерского тренинга упражнения основой собственной техники.

Ключевые слова: актер; режиссер; Михаил Чехов; метод; техника актера; «психологический жест»; «ритмический жест идеи»

\title{
FORMATION AND DEVELOPMENT OF THE MAIN PRINCIPLES OF M. CHEKHOV'S THEATER SYSTEM IN THE CONTEXT OF CHANGING THE ACTOR'S WORLD PERCEPTION
}

\author{
Nataliia Donchenko ${ }^{1 a}$, Nataliia Sokolenko ${ }^{2 a}$ \\ ${ }^{1}$ Honored Artist of Ukraine, Professor; \\ e-mail: donchenko.nata1@gmail.com; ORCID: 0000-0003-1484-6800 \\ ${ }^{2}$ Master; e-mail: quitrack23@gmail.com; ORCID: 0000-0002-5978-2807 \\ ${ }^{a}$ Kyiv National University of Culture and Arts, Kyiv, Ukraine
}

\begin{abstract}
The purpose of the work is to analyze the formation and development of the main principles of M. Chekhov's theatrical system in the context of changing the actor's worldview of theatrical art. Investigate the theatrical and pedagogical system M. Chekhov as one of the world's leading theatrical practices, as a synthesis of complex complementary and mutually enriching intercultural processes; to determine the artist's influence on the reform of the European and American schools of acting art. The research methodology is based on the use of the following scientific approaches: cognitive - for in-depth study of the diversity of M. Chekhov's creative activity as the author of the unique acting "Chekhov's System"; cultural is to compare and confront historical, pedagogical and art components in the activities of M. Chekhov; analytical is to identify the basic principles of the methodology of acting skills of $\mathrm{M}$. Chekhov. Scientific novelty. The acting and directing activity of $\mathrm{M}$. Chekhov in the context of features of preparation actor's technique and
\end{abstract}


development of own method of production harmonization have been investigated; the specifics of innovative concepts of M. Chekhov's theatrical directing methods have been determined; the influence of the master's directing activity on the development of modern world theatrical practice in the context of the worldview of the actor has been characterized. Conclusions. M. Chekhov's activities were aimed at creating a new theater, both literally and figuratively, using techniques developed through teaching and experiments. The study of Mikhail Chekhov's methodology in the context of the specifics of modern acting training allows us to note that the attitude to the creative and pedagogical heritage of $\mathrm{M}$. Chekhov is special, as recognized professional actors for more than half a century consider his method the foundation for further creative research, and the exercises developed for acting training are the basis of their own technique.

Keywords: actor; director; Mikhail Chekhov; method; actor's technique; "psychological gesture"; "Rhythmic gesture of the idea" 